\title{
Ethnolinguistic identity and social cognition: Language prejudice as hermeneutic pathology
}

\author{
David Herman \\ Department of English, Ohio State University \\ 164 W. 17th Avenue, Columbus, OH 43210-1370, USA \\ e-mail: herman.145@osu.edu
}

\begin{abstract}
Analysts studying the nexus between language and ethnic identity have characterized ethnolinguistic ideologies as the deep structure of overt language practices. By contrast, this exploratory analysis argues for the advantages of shifting from a multi-level to a single-level explanatory model, consisting of interpretive frames and data (= aspects of sociocommunicative behavior) interpreted by way of those frames. The single-level model affords, arguably, a more unified treatment of people's everyday inferences about ethnolinguistic identity, on the one hand, and research paradigms for studying language as an ethnosemiotic resource, on the other hand. Yet the "singletiered" model does not void socioideological considerations. Instead, it assumes that a continuum stretches between (1) entrenched language prejudices, (2) efforts to use language theory to question or dislodge such prejudices, and (3) the moment-by-moment hypotheses and inferences in terms of which humans make sense of their conspecifics' linguistic behavior, along with other ethnosemiotic cues.
\end{abstract}

\section{Introduction}

In a recent discussion of ethnolinguistic identity vis-à-vis the development and current status of African American Vernacular English (AAVE), Walt Wolfram noted suggestively that although most of the world's languages are associated with ethnocultural groups, "language is neither a necessary nor [a] sufficient condition for ethnic group 
membership" subordinated language variety to experience prejudice or, for that matter, outright discrimination. Rather, what enables the dominant culture's exclusion or subordination of minority groups is a complex system of assumptions, norms, and practices, whose multifacetedness creates a sort of built-in redundancy and reduces the weight carried by any one component of the system. Encompassing various sources and types of information — from skin color and dress to religious practices and food choices - this framework organizes experience into subsystems of ethnosemiotic cues more or less accessible to conscious awareness, with language constituting just one of the subsystems at issue. Conversely, when isolated from the larger ecology of ethnosemiotic conventions, linguistic behaviors do not suffice to qualify those who instantiate them as members of particular groups. Hence the controversial status of white rappers who, like Eminem, incorporate elements of AAVE into their performance styles but do so at the risk of being viewed as re-appropriating or co-opting indigenous black culture - and thereby threatening to diminish the critical and oppositional energies from which it takes its distinctive character.

But if language is neither a requirement for nor a guarantee of ethnic identity, what then accounts for the pervasive and persistent tendency, on the part of sociolinguistic researchers as well as nonspecialists, to associate language and ethnicity? Using Wolfram's and others' ideas as a springboard for my discussion, in this exploratory discussion I examine foundational issues facing theorists who study, from various disciplinary perspectives, the contingent and variable link between language and ethnic identity. Because of the complexity of the language-ethnicity nexus, analysts have sought to illuminate this nexus by synthesizing insights from a range of fields. Here I shall follow suit, bringing ideas from sociolinguistic theory into dialogue with models developed in cognitive linguistics and text processing, discourse analysis, evolutionary psychology, hermeneutic theories of

\footnotetext{
Wolfram, Walt. Linguistic subordination and ethnolinguistic identity: The construction of African American Vernacular English. Paper presented at a conference on "Contextualizing Ethnicity: Conversations across Disciplines" sponsored by NC State University's College of Humanities and Social Sciences and the Center for International Ethnicity Studies; Raleigh, USA, February 2003. Hereinafter referred to as Wolfram 2003.
} 
interpretation, and cultural semiotics, among other disciplines. But though my account thus draws on concepts from multiple research traditions, my chief aim is to work toward an explanatory framework with maximal economy - that is, one that combines the greatest scope with the fewest underlying assumptions. In other words, I seek to maximize opportunities for cross-disciplinary exchange concerning the language-ethnicity link by sketching a framework for inquiry that is attached to a very spare and thus highly transportable conceptual scaffolding. To put the same point yet another way, sometimes thin rather than thick descriptions are needed (contra Geertz 1973), because the thicker the description of a process or phenomenon, the more embedded that description is in the specific analytic paradigm that provides the descriptive nomenclature. To promote new synergies among the fields concerned with how language shapes and is shaped by ethnic identity, it may be necessary to build a stripped-down model on which diverse traditions of inquiry can then re-converge, each thickening the basic account that provides a common foundation for cross-disciplinary work.

\section{Language and ethnicity: From a multi-level to a single-level explanatory model}

The link between language practices and ethnocultural groups is both synchronically and, as recent accounts of the development of AAVE suggest (see Poplack, Tagliamonte 2001; Rickford 1999; Wolfram, Thomas 2002), diachronically variable. However, if there is one main lesson to be learned from the past 30-40 years of sociolinguistic research on language variation, it is that variability should not be confused with randomness. The linguistic code associated with English licenses alternative ways of saying the same thing - [ta:m] vs. [taIm], hoagie vs. sub, I ain't goin' nowhere vs. I am not going anywhere, and gimme a beer vs. would you please give me a beer? Sociolinguists have appealed to social, situational, and sociopsychological factors - including regional background, gender, age, class, ethnicity, and degree of familiarity between interlocutors - to account for why particular selections are made from among semantically equivalent speech productions. Thus, in questioning the extent to which language and ethnicity can in fact be considered co-variant, 
Wolfram (2003) revisits a basic sociolinguistic research hypothesis. His account suggests that the correlation in question cannot be explained without appeal to other, socioideological factors - factors that were outside the scope of the models originally developed by dialectologists and sociolinguists to study variety in language. ${ }^{2}$

From this perspective, the tendency to associate language and ethnicity can be viewed as parasitic on social processes situated at another, more fundamental explanatory level; those further processes determine how language varieties become socially embedded in the first place. As Wolfram (2003) puts it, "linguistic boundaries are permeable, constructed notions defined more adequately on the basis of sociopolitical and ideological considerations than on the basis of linguistic structures and sociolinguistic relationships". 3 Hence, to account for observed interconnections between the linguistic and the social - interconnections that inform everyday communicative behavior as well as media portrayals and public debates like those

2 Drawing on the work of cultural theorists such Bourdieu (1991) and Foucault (1980), analysts in fields such as applied linguistics, sociolinguistics, and linguistic anthropology have brought these socioideological factors within the purview of research on a range of topics. Topics explored from this perspective include nonstandard varieties of languages; metalinguistic or metapragmatic awareness on the part of language users, who categorize speech events as well as speakers using specific kinds of verbs for reported discourse (he argued versus he speculated), labels for members of groups (e.g., redneck, college boy), and other metapragmatic signalling strategies; the nature and distribution of ethnolinguistic boundaries within and across speech communities; the interrelations among language use and educational practices; and the gender-marking and -creating functions of linguistic forms deployed in more or less distinct communities of practice. Overviews of relevant work in these and other areas can be found in Schieffelin, Woolard, Kroskrity (1998) and Kroskrity (2000); Woolard (1998) provides an especially useful summary of trends and approaches. This research provides a background for the present analysis, which seeks to identify core processes underlying and thus linking all these (apparently heterogenous) sociocommunicative phenomena. As I suggest below, those core processes involve the alignment or non-alignment of frames or typifications with specific sociocommunicative behaviors interpreted by way of those frames.

3 Cf. Roberts (1998: 109-110): "Despite disciplinary differences, one of the most remarkable trends in current thinking about language and culture is a broad consensus on the constructed nature of social reality. Ideas about social relations, social identities, national and ethnic groups and institutions are understood as being formed out of interaction and out of the dominant and conflictual knowledge and assumptions that circulate within society". 
surrounding the Ebonics controversy - it is necessary to excavate another, deeper level of the social. The processes operating at that more fundamental level work to naturalize linguistic boundaries as markers of ethnocultural divisions, which are in turn reified as found, not made.

By contrast, in the remainder of this discussion, I wish to argue the merits of a framework for studying language and ethnicity that shifts from a multi-level to a single-level explanatory model. Instead of construing ethnolinguistic ideologies as the deep structure of language practices, I outline what I take to be a more minimalist model consisting of interpretive frames and data (= aspects of sociocommunicative practice) interpreted by way of those frames. ${ }^{4}$ Occam's razor is not my only reason for proposing the alternative account; beyond this, the single-level model affords, in my view, a more unified treatment of people's everyday inferences about ethnolinguistic identity, on the one hand, and research paradigms for studying language as an ethnosemiotic resource, on the other hand. It also encompasses all levels of language organization, from phonetic to discourse-level features. By the same token, the "single-tiered" model does not void socioideological considerations from research on language and ethnicity. Instead, it assumes that a continuum stretches between (1) entrenched language prejudices resistant to modification in light of contravening data, (2) efforts to use language theory to question or dislodge such prejudices, and (3) the moment-by-moment hypotheses and inferences in terms of which humans make sense of

4 I use the term frame in parallel with what Artificial Intelligence researchers (Minsky 1975; Rumelhart 1981; Schank, Abelson 1977) sometimes refer to as schemata, i.e., "structures of expectation' associated with situations, objects, people, and so on" (Tannen 1993a: 7). As characterized by researchers in fields including anthropology (Bateson 1954), sociology (Goffman 1974), and discourse and narrative analysis (Tannen 1993a, 1993b; Herman 2002: 85-113; Jahn 1997), frames allow previous experiences to be stored in the memory as structured repertoires of expectations about current and emergent experiences. In parallel with what Schutz (1962) characterized as typifications, or "normalized" representations based on more or less heterogenous instances of general processes (buying groceries, booting up a computer, engaging in classroom discourse, etc.), frames structuring sociocommunicative practice guide the production and interpretation of discourse until such time as linguistic, interactional, or other cues prompt the modification of a given frame or else its rejection in favor of some other emergent or competing frame. 
their conspecifics' linguistic behavior, along with other ethnosemiotic cues.

In the single-tiered model, both language practices and research on those practices can be viewed as involving a more or less robust interplay between frame-driven or top-down and data-driven or bottom-up processing strategies; this interplay constitutes a version of what is known in other contexts as the hermeneutic circle, whereby understanding of the whole affects interpretation of the part and interpretation of the part in turn (re)shapes understanding of the whole (Bontekoe 1996). The frame-data nexus structures the relation between linguistic behaviors - accents, lexical choices, morphosyntactic features, discourse-level phenomena - and inferences about those behaviors. To take a discourse-level example from face-to-face interaction, using a "joke" frame as opposed to an "insult" frame can lead to very different interpretations of one and the same utterance. Conversely, if enough utterances of a particular type arise during our interaction, I may have to shift from the theory that my interlocutor is just kidding to the theory that he or she really has it out for me. Likewise, at the level of vocabulary, depending on what sorts of lexical items accumulate over the course of an interaction (soda or pop? bucket or pail?), my initial theory about my interlocutor's regional background may have to give way to a different theory. More generally, as linguistic information accrues over the course of an interaction or for that matter an extended theoretical inquiry, the interpretive frames used to make sense of such data may need to be modified or else abandoned in favor of other, competing frames.

The same goes for working theories about an interlocutor's ethnolinguistic identity. Those who (as Wolfram 2003 reports) revealed their bias against African American callers seeking to rent apartments no doubt used a variety of linguistic cues to shift from a default, generic frame that did not commit them to any interpretation of a caller's ethnocultural status to a more nefariously particularized frame, which was both the rationale for and the result of discriminatory business practices. My point is not to excuse such practices, of course, but rather to situate them in the larger interpretive ecology from which they derive their internal structure as well as their pernicious effects. Arguably, engaging in the ongoing calibration of frames and data is a phylogenetic legacy — a species-general imperative arising from 
evolutionary pressures, not a racist idiosyncrasy. ${ }^{5}$ At issue are basic and general sociocognitive principles by virtue of which typifications based on prior experience are subsequently used as frames for interpreting and organizing thought and conduct (Schutz 1962). It is just that language prejudices involve the persistent use of invalid typifications, i.e., the perpetuation of frames manifestly at odds with the data for which they purportedly account. Linguistic behaviors different from those associated with the standard trigger an interpretive frame whereby the behaviors are construed as inferior to the standard. The root question posed by manifestations of language prejudice can thus be reformulated in the following terms: why, in some domains of language practice, do frames incongruent with accumulating data and blatantly controverted by linguistic theory nonetheless persist as ways of seeing, as structures for understanding the world?

Addressing this question requires recognizing that there is a difference in degree, not kind, between language prejudices and theorybuilding activities of a more positive and progressive sort. The bigot's self-fulfilling prophecy and the best intentions of learning through experience are separated by a razor's edge: namely, the nature of the interface between frames and data. This isomorphism explains, in part, the difficulty of using language theory to "cure" native biases about language practices, which constitute species of theory-building in their own right. Linguistic science is fundamentally continuous with folklinguistic knowledge, given that the goal of researchers, too, is a goodness-of-fit between interpretive frames and linguistic data - as is attested, for example, by the ongoing debate among the Anglicist, Creolist, and Neo-Anglicist positions vis-à-vis the origin and development of African American Vernacular English, or AAVE (cf. Wolfram, Thomas 2002 for an overview; for a dissenting position, see Poplack, Tagliamonte 2001). Similarly, in his classic study of ways in which speakers more or less consciously manipulate cues associated with linguistic difference, what Labov (1972) characterized as

5 In this sense, study of the diachronic profile of the interface between typifications and language practices falls within the domain of evolutionary psychology, which explores evidence for the development of human intelligence at a species level and builds hypotheses concerning how current-day cognitive abilities are an outgrowth of that evolutionary legacy. Relevant studies include Barkow, Cosmides, Tooby (2002); Gazzaniga (1994); and Tomasello (2001). 
indicators, markers, and stereotypes represent a point of convergence between linguistic theory and folk linguistics. In ethnolinguistic contexts, these categories can be taken to refer to classes of ethnosemiotic cues embedded in frames that are brought to bear, in a more or less default manner, on the cues' interpretation. At one end of the spectrum, indicators automatically trigger application of a frame. At the other end, stereotypes have already been reframed, in a sense, because once a cue becomes subject to overt commentary, those who comment on the cue are no longer in the grip of the frame by virtue of which it seemed transparently linked to an ethnocultural group. Stereotypes are thus frames made visible - i.e., brought within the scope of native ethnolinguistic theorizing.

\section{Rejoining the circle}

But the foregoing considerations only defer the question at hand: if language prejudices constitute (bad) theories in and of themselves, why do those theories persist in the face of better theories - theories revealing the systematicity of non-standard dialects, for instance, and thus the untenability of claims concerning the "inferiority" of vernacular speech? In this connection, note that although they are distinguished by the degree of automaticity involved in their manipulation and interpretation, all three categories of cues identified by Labov (1972) - indicators, markers, and stereotypes - fall within the metapragmatic domain, as characterized by Silverstein (1993; cf. Lucy 1993). This domain encompasses the competencies undergirding what Roberts (1998: 111) succinctly characterizes as "speakers" capacity to comment on language use and give off signals about social relationships". Besides linking language use and language theory, such metalinguistic competencies suggest how language prejudice can be situated within the broader ecology of human cognition, in which metacognition, or thinking about thinking (Moses, Baird 1999), can play a more or less prominent role - depending on factors that include the complexity of a given processing task and the availability of the cognitive resources needed to perform it. From this perspective, language prejudice needs to be investigated as the close kin of what cognitive scientists have termed judgment heuristics — that is, general "coping strategies" by virtue of which people arrive at determinations 
based not on exact calculations but on heuristic guides, or rules of thumb. Heuristics of this sort, influentially explored by Tversky and Kahneman (1974; cf. also Kahneman, Slovic, Tversky 1982), enable people to determine rapidly the probability of rain or the size of a crowd on the street - though they also lead to systematic errors that researchers have technically defined as the biases attendant upon distinct kinds of judgment heuristics (see Fischhoff 1999). In essence, prejudice is a byproduct of the same kinds of quick-and-dirty heuristics, which may be put to non-pernicious as well as socially destructive uses - whenever an information-rich environment causes a processing overload and prompts the use of cognitive shortcuts. Given that humans' basic cognitive endowment has achieved relative stability at this point in our evolutionary history, it seems unlikely that people will ever stop using heuristics of this sort. The challenge, then, is to militate against their indiscriminate application across all contexts - in effect, to increase the range, diversity, and explanatory adequacy of the heuristics used to manage the informational richness of ethnosemiotic cues in particular.

We can come at this same issue from another direction - namely, by emphasizing the basic asymmetry between frames and data, typifications and the specific practices or behaviors on which they are based (and which they are in turn used to interpret). On the one hand, it is impossible to make sense of an isolated datum in the absence of a frame that allows it be chunked with other data and so made comprehensible as an element of some larger experiential structure. ${ }^{6}$ But on the other hand, it is possible for frames to become so entrenched, taken-for-granted, or "naturalized" that the hermeneutic circle is interrupted and some newly interpreted part is prevented from impinging on what is in reality an always only emergent understanding of the whole. In this sense, language prejudices can be recharacterized as grossly and reprehensibly data-resistant or, at the limit, data-impervious frames. At issue are top-down processing strategies that, more or less widely shared within a social collectivity,

\footnotetext{
6 Thus, in the sociophonetic experiment conducted by Thomas and Reaser (2004), which aimed to determine which phonetic cues listeners use to identify a speaker's ethnicity, informants were (in effect) prompted to activate frames insofar as they were asked to make identifications in terms of pre-given ethnolinguistic categories. The design of the experiment itself, in other words, afforded frames for contextualizing the phonetic details under investigation.
} 
resist being brought into a complementary relation with bottom-up strategies, as well as with other frames defined by their perviousness to data. The more naturalized or entrenched a frame, the less amenable it is to being modified or replaced - indeed, the less possible it is to discern features of the world that would warrant modifying or replacing the frame in question.

Given the data-resistant profile of language prejudices, how could such frames ever be denaturalized, that is to say, demonstrated to be contingent theoretical constructs rather than reflections of the way things really are? The only viable strategy for countering prejudice is arguably to propagate, as widely as possible, alternative frames more sensitive to the confirmatory as well as disconfirmatory pressure of data. Ideology is a way of describing what happens when the hermeneutic circle is broken; a preconceived whole is forcibly imposed on parts in an effort to homogenize the different, to eradicate the other in the name of the same. Paradoxically, then, only by refusing to step outside the circle of interpretation can interlocutors as well as analysts begin to open the closed system of language prejudice - and thus start coming to terms with diversity.

\section{References}

Barkow, Jerome H.; Cosmides, Leda; Tooby, John (eds.) 1992. The Adapted Mind: Evolutionary Psychology and the Generation of Culture. New York: Oxford University Press.

Bateson, Gregory 1954. Steps to an Ecology of Mind. New York: Ballantine.

Bontekoe, Ronald 1996. Dimensions of the Hermeneutic Circle. Atlantic Highlands: Humanities Press International.

Bourdieu, Pierre 1991. Language and Symbolic Power. Cambridge: Polity. [Thompson, J. B. (ed.); Raymond, G; Adamson, M. (trans.)]

Fischhoff, Baruch 1999. Judgment heuristics. In: Wilson, R. A.; Keil, F. C. (eds.), The MIT Encyclopedia of the Cognitive Sciences. Cambridge: MIT Press, 421-23.

Foucault, Michel 1980. Power/knowledge: Selected Interviews and Other Writings, 1972-1977. New York: Pantheon Books. [Gordon, C. (ed.); Gordon, C. et al. (trans.)]

Gazzaniga, Michael S. 1994. Nature's Mind: The Biological Roots of Thinking, Emotions, Sexuality, Language and Intelligence. New York: Basic Books.

Geertz, Clifford 1973. The Interpretation of Cultures. New York: Basic Books.

Goffman, Erving 1974. Frame Analysis: An Essay on the Organization of Experience. New York: Harper and Row. 
Herman, David 2002. Story Logic: Problems and Possibilities of Narrative. Lincoln: University of Nebraska Press.

Jahn, Manfred 1997. Frames, preferences, and the reading of third-person narratives: Toward a cognitive narratology. Poetics Today 18(4): 442-468.

Kahneman, Daniel; Slovic, Paul; Tversky, Amos (eds.) 1982. Judgment under Uncertainty: Heuristics and Biases. New York: Cambridge University Press.

Kroskrity, Paul V. (ed.) 2000. Regimes of Language: Ideologies, Polities, and Identities. Santa Fe: School of American Research Press.

Labov, William 1972. Sociolinguistic Patterns. Philadelphia: University of Pennsylvania Press.

Lucy, John A. (ed.) 1993. Reflexive Speech: Reported Speech and Metapragmatics. Cambridge: Cambridge University Press.

Minsky, Marvin 1975. A framework for representing knowledge. In: Winston, P. (ed.), The Psychology of Computer Vision. New York: McGraw-Hill, 211277.

Moses, Louis J.; Baird, Jodie A. 1999. Metacognition. In: Wilson, R. A.; Keil, F. C. (eds.), The MIT Encyclopedia of the Cognitive Sciences. Cambridge: MIT Press, 530-532.

Poplack, Shana; Tagliamonte, Sali 2001. African American English in the Diaspora. Malden: Blackwell.

Rickford, John R. 1999. African American Vernacular English. Malden: Blackwell Publishers.

Roberts, Celia 1998. Awareness in intercultural communication. Language Awareness 7(2): 109-27.

Rumelhart, David E. 1981. Schemata: The building blocks of cognition. Cognitive Science 5: 33-57.

Schank, Roger C.; Abelson, Robert P. 1977. Scripts, Plans, Goals and Understanding: An Inquiry into Human Knowledge Structures. Hillsdale: Lawrence Erlbaum.

Schieffelin, Bambi B.; Woolard, Kathryn A.; Kroskrity, Paul V. (eds.) 1998. Language Ideologies: Practice and Theory. New York: Oxford University Press.

Schutz, Alfred 1962. Common-sense and the scientific interpretation of human action. In: Collected Papers, vol. 1. [Natanson, M., ed.] The Hague: Martinus Nijhoff, 3-47.

Silverstein, Michael 1993. Metapragmatic discourse and metapragmatic function. In: Lucy 1993: 33-58.

Tannen, Deborah 1993a. Introduction. In: Tannen, Deborah (ed.), Framing in Discourse. Oxford: Oxford University Press, 3-13.

Tannen, Deborah 1993b. What's in a frame? Surface evidence for underlying expectations. In: Tannen, Deborah (ed.), Framing in Discourse. Oxford: Oxford University Press, 14-56.

Thomas, Erik R.; Reaser, Jeffrey 2004. Delimiting perceptual cues used for ethnic labeling of African American and European American voices. Journal of Sociolinguistics 8: 54-86. 
Tomasello, Michael 2001. The Cultural Origins of Human Cognition. Cambridge: Harvard University Press.

Tversky, Amos; Kahneman, Daniel 1974. Judgment under uncertainty: Heuristics and biases. Science 185: 1124-1131.

Wolfram, Walt; Thomas, Erik R. 2002. The Development of African American English: Evidence from an Isolated Community. Malden: Blackwell.

Woolard, Kathryn A. 1998. Introduction: Language ideology as a field of inquiry. In: Schieffelin, Woolard, Kroskrity 1998: 3-47.

\section{Этнолингвистика и социальное познание: языковой предрассудок как герменевтическая патология}

Ученые, изучающие связь между языком и национальным идентитетом, описывали этнолингвистические идеологии как глубинные структуры первичных языковых практик. Настоящий анализ доказывает, что гораздо целесообразнее перейти от многоуровневой аналитической модели к одноуровневой модели, которая содержала бы в себе интерпретационные фреймы и данные (т.е. аспекты социокоммуникативного поведения), которые через эти фреймы интерпретируются. Одноуровневая модель, безусловно, позволяет более адекватно рассматривать, с одной стороны, ежедневные выводы людей об этнолингвистических идентитетах, а с другой - исследовательские парадигмы языка как этносемиотического ресурса. Кроме того, одноуровневый подход не свободен от социоидеологических влияний. Наоборот, такой подход предполагает, что простирается некий континуум между (1) языковыми предрассудками, (2) попытками использования теории языка для опровержения этих предрассудков и (3) спонтанными гипотезами и выводами, на основе которых люди осмысляют языковое поведение своих сотоварищей (наряду с другими этносемиотическими указаниями).

\section{Etnolingvistika ja sotsiaalne taju: Keeleline eelarvamus kui hermeneutiline patoloogia}

Keele ja rahvusliku identiteedi vahelist seost uurinud teadlased on etnolingvistilisi ideoloogiaid kirjeldanud kui esmatasandi keelepraktikate süvastruktuuri. Käesolev analüüs aga väidab, et on märksa otstarbekam minna mitmetasandiliselt analüütiliselt mudelilt üle ühetasandilisele mudelile, mis koosneks tõlgenduslikust raamistikust ja andmetest (st sotsiokommunikatiivse käitumise aspektidest), mida antud raamide kaudu 
tõlgendatakse. Väidan, et ühetasandiline mudel võimaldab oluliselt ühtlasemalt käsitleda inimeste igapäevaseid järeldusi etnolingvistiliste identiteetide kohta ühelt poolt ning keele kui etnosemiootilise varamu uurimisparadigmasid teiselt poolt. Siiski ei ole ühekihiline lähenemine puhas sotsioideoloogilistest kaalutlustest. Vastupidi, nimetatud lähenemine eeldab, et (1) juurdunud keelelised eelarvamused, (2) keeleteooria kasutamine nende eelarvamuste kummutamiseks ja (3) hetkelised hüpoteesid ning järeldused, mille pinnalt inimesed teevad järeldusi oma kaaslaste keelelise käitumise kohta (sh teised etnosemiootilised vihjed), moodustavad kõik ühe pideva kontiinumi. 
